\title{
Credit risk management and financial performance of selected commercial banks in Nigeria
}

\author{
Alalade S. Yimka ${ }^{a}$, Agbatogun Taofeek ${ }^{b}$, Cole Abimbolaa, Adekunle Olusegun ${ }^{c}$ \\ a Department of Economics, Banking and Finance, Babcock Business School, Babcock University, Nigeria. \\ b Department of Accountancy, Abraham Adesanya Polytechnic, Nigeria. \\ c Department of Business Administration, Gateway Polytechnic, Nigeria. \\ *Corresponding author's e-mail: samyimka@gmail.com
}

H I G H L I G H T S:

1. This paper is the first time to consider the effective tax rates set between 0 and 1 and this range is more meaningful for the ETRs.

2. This paper attempts to use the panel data models with two-sided censoring suggested by Alan, Honor'e, and Leth-Petersen (2014) to study the determinants of ETRs for the listed on China stock markets.

3. For a comparison with previous research, this article adopts four definitions of ETR and the empirical results demonstrate fruitful conclusions.

4. This model can add more observations especially the observations with tax preferences

\section{Article History}

Received: 24-11-2014

Revised received: 10-12-2014

Accepted: 26-12-2014

Available online: 28-12-2014

Keywords:

Credit risk management;

Financial performance:

Non-performing loan;

Return on equity.

JEL Classification:

C21; C52; H25.

(C) 2015 The Authors. This is an open access article under the terms of the Creative Commons Attribution License 4.0, which allows use, distribution and reproduction in any medium, provided the original work is properly cited.

\subsection{Introduction}

The increased competition associated with the process of capitalization, liberalization and globalization and the attempts of Nigerian banks to increase their presence in other markets may have affected the efficiency and credit risk of the Nigerian banking institutions. The first of these aspects, already analyzed in other studies, is based on the incentive to the banks to reduce costs and to improve the management of their resources in order to gain competitiveness. The second aspect, which has not yet been analyzed, is explained by the poorer knowledge of the new markets by the newly entered banks and/or the greater permissiveness in the acceptance of risk with a view to increasing the market share in certain sectors and/or regions. Despite the importance of these two aspects, banking literature has usually analyzed banking efficiency without considering them together. 
The risk focused examination process has been adopted to direct the inspection process to the more risk areas of both operations and business. Skills in risk-focused supervision are continually being developed by exposing examiners to relevant training. By adopting this approach, the banking industry, and specifically the commercial banks are sensitized on the need to have formal and documented risk management frameworks. Notably, the more complex a risk type is, the more specialized, concentrated and controlled its management must be (Seppala, 2000; Matz \& Neu, 1998; Ramos, 2000). Financial institutions are exposed to a variety of risks among them; interest rate risk, foreign exchange risk, political risk, market risk, liquidity risk, operational risk and credit risk. In some instances, commercial banks and other financial institutions have approved decisions that are not vetted; there have been cases of loan defaults and nonperforming loans, massive extension of credit and directed lending.

Credit risk is the possibility that the actual return on an investment or loan extended will deviate from that, which was expected (Conford, 2000). Coyle (2000) defines credit risk as losses from the refusal or inability of credit customers to pay what is owed in full and on time. The main sources of credit risk include, limited institutional capacity, inappropriate credit policies, volatile interest rates, poor management, inappropriate laws, low capital and liquidity levels, directed lending, massive licensing of banks, poor loan underwriting, reckless lending, poor credit assessment, no non-executive directors, poor loan underwriting, laxity in credit assessment, poor lending practices, government interference and inadequate supervision by the central bank. To minimize these risks, it is necessary for the financial system to have; well-capitalized banks, service to a wide range of customers, sharing of information about borrowers, stabilization of interest rates, reduction in non-performing loans, increased bank deposits and increased credit extended to borrowers. Loan defaults and non-performing loans need to be reduced (Basel Committee on Banking Supervision, 2006).

Commercial banks employed different credit risk management policies majorly determined by; ownership of the banks (privately owned, foreign owned, government influenced and locally owned), credit policies of banks, credit scoring systems, banks regulatory environment and the caliber of management of the banks (Nworji, Olagunju \& Adeyanju, 2011). Banks may however have the best credit management policies but might not necessarily record high profits. In addition, although there are industry standards on what is a good credit policy and what is not and further banks have different characteristics. The market may thus be seen to regard an individual banks' poor performance more lenient when the entire banking sector has been hit by an adverse shock such as a financial crisis. Banks may be forced to adjust their credit policy in line with other banks in the market where a herding behavior is practiced by banks (Altman, 2008). Looking at the emphasis that is laid on credit risk management by commercial banks the level of contribution of this factor to profits has not been analyzed. Petersen \& Rajan (1995) notes that expanding lending in the short-term boosts earnings, thus the banks have an incentive to ease their credit standards in times of rapid credit growth, and likewise to tighten standards when credit growth is slowing.

\subsection{Statement of the problem}

In Nigeria, commercial banks play an important role in mobilizing financial resources for investment by extending credit to various businesses and investors. Lending represents the heart of the banking industry and loans and advances are the dominant assets as they generate the largest share of operating income. Loans however expose the banks to the greatest level of risk. Many banks that collapsed in the late 1990's and up to the recent restructuring of the commercial banks in Nigeria were as a result of the poor management of facility which was portrayed in the high levels of non-performing loans. Looking at the emphasis that is laid on credit risk management by commercial banks in the recent time, the level of contribution of this factor to financial performance has not been analyzed which called for this study. Researcher has therefore turned to the study of credit risk management, which offers natural experiments for the betterment performance assessment of commercial banks in Nigeria.

The broad objective of this paper is to examine the relationship between credit risk management and financial performance of commercial banks in Nigeria. The specific objectives are to: (i) examine the significance of credit risk management on the financial performance of commercial banks in Nigeria; (ii) analyze the financial performance of commercial banks under study; (iii) determine and evaluate the effect of non-performing Loan on the profitability of commercial banks in Nigeria;

Therefore, our hypothesis to be tested in this study are: (i) credit risk management has no significant effect on financial performance in Nigerian banks; (ii) there is no significant relationship between loan and advances management of commercial banks and their Profitability performance; and (iii)non-performing loans and advances have no significant effect on financial performance of commercial banks.

At the end of this study, it is expected that the study would be of immense benefit to a lot especially the people working in the banking industry, these includes, bankers, financial analysts, the bank managers, internal auditors, the top management of commercial banks as significant relationship between Credit risk management components 
and financial performance of commercial banks using ratio analysis would be considered. It is also expected to serve as reference materials for students, lecturers and researchers on the same or similar subjects of asset quality, non-performing loan and credit risk management, in relation to financial performance of commercial banks in Nigeria.

\section{$2.0 \quad$ Review of related literature}

Empirical evidence on bank loan recoveries (Keisman, 2009) and on corporate bonds by seniority (Altman \& Karlin, 2009) based on the average prices of these securities just after the date of default. Surprisingly, the highest mean recovery rates were on senior unsecured bonds (60\%) and bank loans (59.4\%) followed by senior secured loans (56.3\%). Although the data from Moody's and Altman were from different periods and samples, it is interesting to note that the recovery on senior unsecured bonds (45.9\%) was significantly lower than senior unsecured bank loans (59.4\%). The estimates of median recoveries on the senior-subordinated and subordinated bonds were very similar. Similar recoveries on defaulted bonds can be found in Varma, Cantor and Hamilton (2003). Altman and Karlin's value weighted mean recovery rate on over 2,300 bond default issues was $37.8 \%$ (Altman, 2006).

Altman and Karlin (2009) further breakdown bond recoveries just after the default date by analyzing recoveries based on the original rating (fallen angels vs. original rating non-investment grade ["junk"] bonds) of different seniorities. For example, we observe that senior-secured bonds, that were originally rated investment grade, recovered a median rate of $50.5 \%$ vs. just $39.0 \%$ for the same seniority bonds that were non-investment grade when issued. These are statistically significant differences for similar seniority securities. Since fallen angel defaults are much more prominent in some years in the United States (e.g., close to 50\% in dollar amount of defaults in 2001 and 2002 were fallen angels prior to default), these statistics are quite meaningful. Note that for senior subordinated and subordinated bonds, however, the rating at issuance is of little consequence, although the sample sizes for investment grade, low seniority bonds were very small. Varma, et. al., (2003) also conclude that the higher the rating prior to default, including the rating at issuance, the higher the average recovery rate at default. Apparently, the quality of assets and the structure of the defaulting company's balance sheets favor higher recoveries for higher quality original issue bonds.

Standard and Poor's (Keisman, 2004) also finds, that during the "extreme stress" default years of 1998 to 2002, the recovery rates on all seniorities declined compared to their longer 1988-2002 sample period. Since 1998 and 1999 were not really high default years, the results of S\&P for 2000-2002 are consistent with Altman, Brady, Resti and Sironi's $(2001,2003)$ predictions of an inverse relationship between default and recovery rates. Indeed, recovery rates were a relatively low $25 \%$ in the corporate bond market for both 2001 and 2002 when default rates were in the double-digits but increased to almost $70 \%$ in 2006 when default rates tumbled to well below average annual levels and then fell to about 22.5\% in 2009 (2Q) as defaults surged (Altman \& Karlin, 2009).

Studies that analyzed bank loans recovery rates were by Asarnow and Edwards (1995) and Eales and Bosworth (1998). The first study presents the results of an analysis of losses on bank-loan defaults based on 24 years of data compiled by Citibank; their database comprises 831 commercial and industrial (C\&I) loans, as well as 89 structured loans (highly collateralized loans that contain many restrictive covenants). Their results (based on "ultimate" recoveries) indicate a LGD of about 35\% for C\&I loans (with larger loans, above US\$ 10 million, showing a somewhat lower loss rate of 29\%); unsurprisingly, the LGD for structured loans is considerably lower (13\%), due to the role played by collateral and covenants in supporting the early default-detection and recovery processes . In the second study, the authors report the empirical results on recovery rates from a foreign bank operating in the United States - Westpac Banking Corporation. The study focuses on small business loans and larger consumer loans, such as home loans and investment property loans.

Shafiq and Nasr (2009) examine the risk management practices followed by commercial banks in Pakistan. The results reveal the following: (i) the greatest exposures banks face are credit risk, liquidity risk, interest rate risk, foreign exchange risk and operating risk; (ii) significant differences exist in the application of risk management practices among public sector and local private commercial banks; and (iii) commercial banks staff basically understand risk management but additional training is required to enhance their expertise in the area.

Hassan (2009) seeks to identify the risks posing the greatest exposure for Islamic banks in Brunei Darussalam and to examine the effectiveness of risk management techniques utilized in these banks. The results of the study reveal that the three major risks affecting the banks are foreign-exchange risk, credit risk and operational risk. Also, Islamic banks are reasonably efficient in managing risk; and risk identification, and risk assessment and analysis are the most influencing variables in risk management practices. Christie-Veitch (2005) examines the status of operational risk management in Trinidad, Barbados and Jamaica; assesses its importance relative to the other risks and reviews the practices for managing operational risk by the financial institutions. The findings are analyzed based on the assessment of compliance with regard to Basel Core Principles for the management of operational risk. 
The study reveals a number of findings: (i) the framework necessary to identify, assess, monitor and control operational risk is still not evident, (ii) the management of operational risk is basically limited to implementing and testing internal controls, (iii) operational profile is not currently reviewed and adjusted based on specific strategies, (iv) the plans to handle business disruption are somewhat in place but are not subject to testing or scenario analysis, (v) best practices with regard to operational risk are not finalized or circulated, and (vi) operational risk management methodologies are not being disclosed by banks.

Wenner, Navajas, Trivelli and Tarazona (2007) investigate the management of credit risk by rural financial institutions in eight Latin American countries. The research reveals that the techniques utilized to reduce credit risk are export-based information-intensive credit technologies, diversification strategies (geographical, sectoral and commodity) and portfolio exposure limits (for example, agriculture is less than $40 \%$ of total lending). Excessive provisioning is also used to internalize and absorb credit risk. Wenner, et al. also reported that few of the institutions are transferring credit risk to third parties and this was a major challenge. The most common instrument used to transfer credit risk is public-funded loan guarantee funds.

Santomero (1997) reviews and evaluates financial risk management systems in a number of North American banks and a few outside of America. He examines both the philosophy and practice of financial risk management. The writer acknowledges that the sophistication of the risk management techniques varies according to the size of the bank. Those at the higher end tend to utilize more advanced and technical risk management techniques. Santomero therefore states that his review encompasses "best practice" as opposed to "average practice". The main findings are as follows: credit risk techniques need to be standardized not only across borrowers but across institutions as well; credit losses need to be closely monitored but systems are not adequate to track the activity; interest rate risk gap management has improved, however the use of book value accounting should be replaced with market value accounting; simulation currently in use is perceived as rather simple and needs to incorporate dynamic hedging techniques that are used in other fixed income models; despite the fact that VAR (value at risk) is a fantastic tool many banks are still using ad hoc approaches in order to determine foreign exchange and other trading limits; crisis models need to be linked to operational factors; illiquidity risk should be defined and built into the illiquid positions, and off-balance sheet risk should be integrated more into the overall decision making process (ibid.). Pagano (2004) examines the rationale for corporate risk-taking and risk management activities, and investigates the motivation for banks engaging in interest rate risk. The sample comprises 241 publicly traded Bank Holding Companies in the United States. The findings reveal that the factors influencing risk management activities of banks are similar to those of non-financial companies. These factors are firm size and financial distress cost. The study also reveals that interest rate volatility has a negative impact on a bank's interest rate risk taking.

Ebnother and Vanini (2007) address the following hypothesis: "The strong autocorrelation between economic cycle demands that we analyze credit portfolio risk in a multi-period setup". They observe that banks usually measure credit risk over a one-year period with the use of VAR (value-at-risk) or ES (expected shortfall). The VAR asks the question "how bad can things get?", while ES asks "if things do get bad what is our expected loss?" Ebnother and Vanini however contend that the risk horizon should indeed be longer than one year since single period risk measures cannot capture the overall effects of systematic shocks occurring over several periods. They therefore recommend an alternative risk measure: the time-conditional expected shortfall (TES). This method utilizes the ES but takes the time horizon into consideration. In summary, from the reviewed studies the following points emerge: the major risks affecting banks are credit risk, interest rate risk, operational risk and foreign exchange risk. Banks are basically efficient in managing risk; however, additional training is still necessary. Operational risk is a major risk but is also quite complex in its measurement. The sophistication of the risk management technique used varies according to the size of the bank. Macroeconomic factors should be taken into account when seeking to assess credit default.

According to Olokoyo (2011), lending is undoubtedly the heart of banking business. So, its management requires considerable skill and dexterity on the part of the bank management. While a bank is irrevocably committed to pay interest on deposits it mobilized from different sources, the ability to articulate loanable avenues where deposit funds could be placed to generate reasonable income; maintain liquidity and ensure safety requires a high degree of pragmatic policy formulation and application. Ezirim (2005) further stressed that bank lending decisions generally are fraught with a great deal of risks, which calls for a great deal of caution and tact in this aspect of banking operations. The success of every lending activity to a great extent therefore, hinges on the part of the credit analysts to carry out good credit analysis, presentation, structuring and reporting. Osayameh (1991) supported this view by stressing that the days of armchair banking are over and that the increasing trend in bad debts and absence of basic business or corporate advisory services in most Nigerian commercial banks, suggest an apparent lack of use of effective lending and credit administration techniques in these banks. Prior to 1984, the bulk of most commercial bank deposit was made up of demand deposit. The position has now changed with the evolution of improved treasury management by corporate savers and customers as well as favorable interest rate now payable on deposits, particularly since interest rates were regulated in 1987. The result of this is additional rise in cost of funds 
for banks. If they are able to meet the cost element in fund and eke out some profits to meet corporate growth and shareholders' expectation, they must really give adequate attention to the single most important source of their earnings- lending and credit administration. Emphasizing this assertion, Osayameh (1996) further stressed that, the major reason for commercial banks' lending is to maximize profit thereby maximizing stakeholders' wealth. The staggering increase in volume of banks credit in Nigeria in 2005 alone lends credence to this assertion. In 2005, aggregate banks credit to the domestic economy grew by $30.8 \%$ to a staggering increase of $\mathrm{N} 2,007.4$ billion compared with the rate of 22.5 per cent, while credit to the core private sector increased by 29.4 per cent to N1,950 billion (Central Bank of Nigeria, 2005). Management of such resources should therefore transcend the use of traditional techniques based mainly on the use of rule-of thumb, hunches and experience. The present volume and complexity of transaction in bank lending and credit administration in Nigeria call for the use of scientific techniques like those of management science and operations research to aid their lending and credit administration (Aremu, Suberu \& Oke, 2010).

Ojo (1999) in a study on roles and failure of financial intermediation by banks in Nigeria revealed that, commercial banks can lend on medium and short term basis without necessarily jeopardizing their liquidity. If they must contribute meaningfully to the economic development, the maturity pattern of their loans should be on a long term nature rather than of short term period". However, Oloyede (1999) claimed that it is generally acknowledged that commercial banking by its nature is highly prone to volatility and fragility - whether arising from exogenous shocks or endogenous policy measures - and therefore, amenable to regulations and supervision. The forms of regulation vary, but in general, they embrace statutory regulations or rules of behavior that may be administratively imposed or that can be guided through a market-oriented approach. One of such guidelines is Section 20 of Bank and Other Financial Institution Act (BOFIA) as amended which restricted the terms and amount of loans that can be given to banks insider. For instance, a bank is not allowed to grant unsecured credit facilities in excess of one year to any of his officers and employees. Usman (1999) also supported this position by stating that a major regulation influencing commercial banks lending in Nigeria is the restriction on the amount of interest they are allowed to pay on deposits in an effort to attract additional depositors and the interest they charge on their fund based activities. Goldfeld and Chandler (1980) claimed that, commercial banks must pay more attention to liquidity than many other types of financial institutions such as life insurance companies. This results from the high turnover of their debt liabilities. A large part of the gross out payments by a bank is met from current gross receipt of funds in the normal course of business.

Ituwe (1983) also asserted that, a bank's ability to grant further advances is checked by the available cash in its vault. Customers' drawings are paid in two ways, either in cash or through bank accounts. Since cheques have to be met in cash in many cases, commercial banks, therefore, have to stock reasonable quantity of cash to meet customers' demands. Where a bank grants advances in excess of its cashing ability, the bank soon runs into difficulty in meeting its customers' cash drawings. Banks lending decisions are also influenced by the past relationship with the borrowers. Past relationship according to him can help banks to obtain more private information, leading to a more accurate understanding of the borrower's business and financial situation. Nevertheless, Olokoyo (2011) and Imeokpararia (2013) discussing on multiple-lending, believed that banks desire to share lending whenever the advantage of greater diversification, in terms of higher cost per project monitoring dominates the cost of free-riding and duplication of efforts.

\subsection{Methodology}

This study is an attempt to provide a critical investigation of impact of credit risk management and performance of commercial banks in Nigeria. This section provides information on the technique or methods used in the manipulation of data collected. The data used in the empirical analysis were collected from the banks' audited and published annual financial-year-end reports of the selected commercial banks observed from 2006 through 2010. The financial statements (disclosure) prepared by the Nigeria commercial banks are standardized according to the requirements of the law of the land and regulates by standards issued by the Central Bank of Nigeria. Based on this guideline, commercial banks in Nigeria follow the same accounting standards which make it possible for direct comparison across banks and over time. The data comprise ten (10) commercial banks, since we have to take into account the banks-specific characteristics in the sample.

The sample of this study contains ten (10) Nigeria commercial banks, which was selected base on the quality and financial strengths of those banks. The sample of this study also contains ten (10) Nigeria commercial banks (Guarantee Trust Bank, First City Monument bank, First Bank, UBA, Diamond bank, Skye banks, Stanbic IBTC Bank, Eco Bank , Access banks, and Zenith Bank), for a minimum period of five (5) years (2006 - 2010). The annual data for these banks during the period was used for calculating key financial ratios in order to assess the performance of the banks. In addition, another source of data would be through reference to the library and the review of different articles, papers, and relevant previous studies. 
The Multiple Regression facilitates determination of effects of the credit risk management variables on the financial performance variable. The regression is specified on the basis of hypothesized functional relationship between the relevant credit risk management and financial performance measures. The E-Views 7 statistical software facilitates computation of the ratios, estimation of numerical values of coefficients (effects) of credit risk management measures in the model and computation of relevant statistics for further analysis and evaluation. Consequently, the model is specified as:

\section{ROE $=\alpha_{0}+\alpha_{1}$ NPLA/PLAL $+\alpha_{2}$ PLAL/TLA $+\alpha_{3}$ NPLA/TLA $+\alpha_{4}$ TLA $/$ TAS $+\mu$}

Where,

- $\alpha_{0}$ is Intercept.

- $\alpha_{i}(i=1,2,3,4)$ are the coefficients or measures of $t, \mu$ is the random variable included in the model to accommodate influences of other variables that might affect profitability but which are not included in the model.

- ROE (Return on Equity), the dependent variable, is a measure of financial performance. It is the ratio of profit after tax to shareholders fund (PAT/SHF).

- NPLA/PLAL is ratio of non-performing loans and advances to provision for loans and advances losses (RNPLAPLAL).

- PLAL/TLA is ratio of provision for loans and advances to total loans and advances (RPLALTLA).

- NPLA/TLA is ratio of non-performing loans and advances to total loans and advances (RNPLATLA).

- TLA/TAS is ratio of total loans and advances to total assets (RTLATAS).

\subsection{Results and discussion}

This is the regression process of obtaining numerical values of the intercept and coefficients (effects) of credit risk management variables as well as the random variable in the model. Estimation of these values is facilitated with the Econometric Views version7 (E-Views 7) statistical software. Estimation technique employed is the Panel Least Squares (PLS). Stacking the data in panel structure results to 50 sample observations for same 2006-2010 study period $(t=5, i=10)$. Below are the results of the regression.

\begin{tabular}{lcccc}
\hline \multicolumn{5}{c}{ Table 01: Panel regression analysis } \\
\hline Variable & Coefficient $\left(\alpha_{\mathrm{i}}\right)$ & Std. Error & t-Statistic & Prob. \\
\hline RNPLA/PLAL & 0.146947 & 0.021445 & 6.852385 & 0.0000 \\
RPLALTLA & 0.001782 & 0.002536 & 0.702431 & 0.4861 \\
RNPLATLA & -0.007946 & 0.006631 & -1.198254 & 0.2372 \\
RTLATAS & -0.127410 & 0.053160 & -2.396743 & 0.0209 \\
\hline R-squared & 0.221407 & F-statistic & 3.128042 & \\
Adjusted R-squared & 0.0150625 & Prob(F-statistic) 0.023853 & \\
Sum Squared Residual & 0.388256 & Durbin-Watson Statistic 1.801477 & \\
\hline
\end{tabular}

Substituting numerical values of the intercept and coefficients of credit risk management measures into the model yields the estimated model below. e is the error of estimate.
$\mathrm{ROE}=$

$$
\begin{aligned}
& 0.146947+0.001782 \text { RNPL } \\
& +0.008041 \text { RTLATAS + e }
\end{aligned}
$$

Estimated coefficients of credit risk management measures in the model are evaluated in two stages. The first stage is discussion of the signs of the coefficients vis-a-vis theorized expectations. The second stage which involves evaluation of statistical significance, explanatory power and test for serial correlation leads to decision on the hypothesis to accept. Relevant statistics for the evaluation are t-statistic for significance of respective effects of the credit risk management measures, F-statistic for overall effect of the credit risk management measures, coefficient of determination (R-squared) for the extent to which the credit risk management measures explain variations in financial performance of the banks during the sample period, and Durbin-Watson statistic for determination of presence or otherwise of serial correlation. Significance is evaluated at $5 \%$ level.

The signs of estimated numerical values of coefficients of the credit risk management measures included in the model are consistent with expectations $\left(\alpha_{0}=0.146947>0, \alpha_{1}=0.001782>0, \alpha_{2}=-0.007946<0, \alpha_{3}=0.127410\right.$ $<0, \alpha_{4}=0.008041>0$ ). These provide the following evidence: i) the lower the proportion of non-performing loans and advances (NPLA) to provision for loans and advances losses (PLAL) the more the return on equity (ROE), and vice versa; ii) the higher the proportion of provision for loan and advances losses to total loans and advances actually used to off-set loans and advances that that turned bad debts, the less the return on equity, and vice versa; iii) the more the proportion of total loans and advances (TLA) that turn out to be non-performing loans and advances (NPLA), the less the return on equity (ROE); and iv) the more the proportion of total assets that goes into loans and advances, the more the return on equity (ROE). Thus, while RNPLAPLAL and RTLATAS exert positive 
effects on ROE, RPLALTLA and RNPLATLA exert negative effects on ROE. Therefore, the directions of the effects are consistent with expectations. Similarly, positive value of the intercept $\left(\alpha_{0}=0.146947\right)$ is as expected, indicating that the banks can sustain some positive financial performance in the absence of those credit risk management variables.

The results also revealed that proportion of non-performing loans and advances to provision for loans and advances has positive effect of greater magnitude than ratio of total loans and advances to total assets, as indicated by their respective coefficients of 0.001782 and 0.008041 . Similarly, proportion of non-performing loans and advances to total loans and advances exerts greater negative effect than proportion of provision for loans and advances losses to total loans and advances, as indicated by 0.127410 and 0.007946 respectively. If the probability associated with t-statistic of the coefficient (effect) of a credit risk management measure on financial performance is less than the specified significance level of $5 \%$, it is significant. That is, prob (t-statistic) $<0.05$. Otherwise, it is not significant. That is, Prob(t-statistic) $>0.05$.

The result table shows that probabilities associated with the coefficients (effects) of RNPLATLA and RTLATAS (0.0209 and 0.0442) are each less than the specified 5\% significance level, while the probabilities associated with effects of RNPLAPLAL and RPLALTLA (0.4861 and 0.2372 ) are each greater than the 5\% level. These provide empirical evidences that, at individual levels, while proportion of non-performing loans and advances to provision for loans and advances (RNPLAPLAL) exerts positive but insignificant effect on ROE, proportion of provision for loans and advances losses to total loans and advances (RPLALTLA) exerts insignificant negative effect on ROE; the share of non-performing loans and advances in total loans and advances (RNPLATLA) exerts significant negative effect on ROE, and the proportion of total assets that goes into loans and advances (RTLATAS) exerts significant positive effect ROE. Therefore, at these levels, the null hypothesis will be rejected for RNPLAPLAL and RPLALTLA respectively, but accepted for RNPLATLA and (RTLATAS) respectively.

From the regression analysis result, the F-statistic of 3.128042 has associated probability 0.023853 . Since the probability is less than the specified 5\% level of significance, the overall effect of the credit risk management variables on financial performance is statistically significance. Therefore, the null hypothesis is rejected and the alternative hypothesis is accepted with respect to the overall effect of credit risk management on financial performance of the banks.

This evaluation determines the extent to which the credit risk management measures included in the model explains variations in financial performance of the banks during the sample period. Coefficient of determination (Rsquared) is the relevant statistic. From the panel regression results, coefficient of determination (R-squared) is 0.221407 or about $22.14 \%$. This low coefficient of multiple determinations implies that these measures of credit risk management exhibit low power in explaining variations in financial performance of the banks during the study period. Thus, it suggests that some other factors or practices of credit risk management not included in the model accounted for more of the variations (about 77.86\%) in financial performance. It further suggests that, perhaps, these credit risk management variables were not optimally managed by the banks, hence their low power in explaining variations in financial performance.

Certain findings have emerged from analysis of data collected for the study. The findings revealed that the lower the proportion of non-performing loans and advances to provision for loans and advances losses, the better the financial performance via increased return on equity. The higher the proportion of provision for loan and advances losses to total loans and advances, that are actually used to off-set loans and advances that that turned bad debts, the less the return on equity cum financial performance, and vice versa. The more the proportion of total loans and advances (TLA) that turn out to be non-performing loans and advances (NPLA), the less the return on equity (ROE). The proportion of non-performing loans and advances to provision for loans and advances has more positive effect than ratio of total loans and advances to total assets, while proportion of non-performing loans and advances to total loans and advances exerts greater negative effect than proportion of provision for loans and advances losses to total loans and advances. In the absence of the credit risk measures considered in the analysis, value of the intercept of the regression line shows that the banks can sustain some positive level of financial performance.

At the 5\% level, while proportion of non-performing loans and advances to provision for loans and advances exerts insignificant positive effect on financial performance of the banks, proportion of provision for loans and advances losses to total loans and advances exerted insignificant negative effect. Therefore, the hypotheses for both measures are accepted. However, while the proportion of non-performing loans and advances to total loans and advances exerts significant negative effect on return on equity, share of total assets that goes into loans and advances exerts significant positive effect on performance. Thus, the hypotheses for effects of these measures are rejected. At the $5 \%$ level of significance, overall effect on financial performance of the credit risk management measures in the study is found to be significant. Consequently, the hypothesis on effect of credit risk management on performance is rejected. The credit risk management measures included in the empirical model exhibited low power in explaining variations in financial performance, despite their overall significant effect, thereby suggesting that, perhaps, the 
credit risk management measures are were not optimally employed by the banks. The analysis equally shows that values of the respective credit risk management variables in one period do not depend on their values in another period so that decisions on them ware basically management policy.

\subsection{Test for autocorrelation}

This evaluation is needed to test for the presence or otherwise of first-order serial correlation (autocorrelation) in the independent variables. That is, it is used to determine whether or not the value of each variable (in this case, each credit risk management measure) in one period, $t$, depends on its value in another period, $t-1$. Relevant statistic for the test is the Durbin-Watson statistic, d. Generally, if the computed value of Durbin-Watson statistic (d) is less than the lower limit $\left(d_{L}\right)$ of Durbin-Watson statistic $\left(d<d_{L}\right)$, there is evidence of positive first-order serial correlation; if $d>d_{v}$, there is no evidence of positive first-order serial correlation. But if computed Durbin-Watson statistic $(d)$ lies between the lower limit $\left(d_{L}\right)$ and upper limit $\left(d_{U}\right)$ of Durbin-Watson statistic $\left(d_{L}<d<d_{U}\right)$, there is inconclusive evidence of presence or otherwise of positive first-order serial correlation (Gujarati \& Porter, 2009).

From the regression results, computed value of Durbin-Watson statistic is 1.801477 (i.e., d = 1.801477). From statistical table, $\mathrm{d}_{\mathrm{L}}=1.378$ and $\mathrm{d}_{\mathrm{U}}=1.721$. Since $\mathrm{d}>\mathrm{d}_{\mathrm{U}}$, there is no evidence of positive first-order serial correlation. Hence, it is concluded that the values of the respective credit risk management variables in one period did not depend on their values in another period such that decisions on them were basically management policy.

\subsection{Conclusions and policy implications}

Based on the analysis and findings thereof, the study concludes that the credit risk management measures considered in this study is relevant in determining financial performance of banks as financial institutions. Reduced share of non-performing loans and advances in provision for loans and advances losses enhances financial performance via increased return on equity. Higher share of provision for loan and advances losses in total loans and advances retards financial performance via return on equity. More proportion of total loans and advances that turn out to be non-performing dwindling return on equity and reduces financial performance. Financial performance is enhanced when increased portion of total assets goes into loans and advances. Increased provision for loan and advances limits financial performance. While some variables exert significant effect on performance, others do not. However, aggregated effect of the credit risk measures on performance is significant. Therefore, the study concludes that credit risk management has significant effect on financial performance of the banks. At the $5 \%$ level of significance, overall effect on financial performance of the credit risk management measures in the study is found to be significant. Consequently, the hypothesis on effect of credit risk management on performance is rejected.

Based on the findings summarized above, and the conclusion thereof, the researchers therefore recommend that, banks maintain minimum level of non-performing loans vis-a-vis provision for loans and advances; minimize provision for loan and advances losses as a share of total loans and advances that would enhance return on equity and strengthen their financial performance; maintain proper proportion of total assets that goes into loans and advances; always strive for optimal policy decision since the values of these credit risk management measured in one period do not depend on their values in another period; reduce the share of non-performing loans and advances in total loans and advances since it exerts greater negative effect than the share of provision for loans and advances losses in total loans and advances and review their existing credit management mechanisms with a view to updating them to minimum global standard as recommended by Basel II.

\section{References}

Altman E. I. 2008. Managing credit risk: challenge for the new millennium. New York: University Press.

Altman, E. \& Karlin, B. 2009. Defaults and returns in the high-yield bond market and market outlook: 2009 FirstHalf Report, NYU Salomon Center, Stern School of Business.

Altman, E. I. 2006. Default recovery rates and LGD in credit risk modeling and practice: An updated review of the literature and empirical evidence." Working paper, NYU: Salomon Center.

Altman, E. I., Resti, A. \& Sironi, A. 2001. Analyzing and explaining default recovery rates. ISDA Research Report, London, December.

Altman, E. I., Brady, B., Resti, A. \& Sironi, A. 2005. The link between default and recovery rates: theory, empirical evidence and implications. Journal of Business, 78 (6): 2203-27. http://dx.doi.org/10.1086/497044

Aremu, O. S., Suberu, O. J. \& Oke, J. A. 2010. Effective credit processing and administration as a panacea for nonperforming assets in the Nigerian Banking System, J Economics Journal, 1 (1): 53-56.

Asarnow, E. \& Edwards, D. 1995. Measuring loss on defaulted bank loans: A 24 year study. Journal of Commercial Bank Lending, 77(7): 11-23. 
Basel Committee on Banking Supervision. 2006. Studies on credit risk concentration: An overview of the issues and a synopsis of the results' from the research task force project. Retrieved from www.bis.org.

Central Bank of Nigeria. 2005. Guidelines for developing risk management: Framework for individual risk element in banks. Retrieved from www.cenbank.org.

Christie-Veitch, C. 2005. Operational risk management practices and the role of capital: A preliminary assessment of three Caribbean countries. The 26th Annual Review Seminar, Research Department, Central Bank of Barbados, July.

Conford, A. 2000. The Basel committee's proposals for revised capital standards: Rationale, design and possible incidence. G-24 Discussion paper series, United Nations, No.3, May.

Coyle, B. 2000. Framework for credit risk management. Chartered Institute of Bankers, United Kingdom.

Eales, R. \& Bosworth, E. 1998. Severity of loss in the event of default in small business and large consumer loans. The Journal of Lending and Credit Risk management, May, 58-65.

Ebnother, S. \& Vanini, P. 2007. Credit portfolios: What defines risk horizons and risk measurement? Journal of Banking and Finance, 31: 3663-3679. http://dx.doi.org/10.1016/j.jbankfin.2007.01.022

Ezirim C. W. 2005. Co-integration and error correction: Representation, estimation and testing. Econometrica, 55, pp. 251-276, doi:10.2307/1913236, http://dx.doi.org/10.2307/1913236. http://dx.doi.org/10.2307/1913236

Goldfield, M. \& Chandler, L. 1986. The economics of money and banking, 9th Ed. New York: Harper and Row Publishers.

Hassan, A. 2009. Risk management practices of Islamic banks of Brunei Darussalam. Journal of Risk Finance, 10(1): 23-37. http://dx.doi.org/10.1108/15265940910924472Imeokpararia, L. 2013. Loan management and the performance of Nigerian banks: An empirical study. The International Journal of Management, Vol: 2/Issue: 1 (January).

Ituwe, C. E. 1985. Elements of practical banking, Ibadan, Oyo State, Nigeria; University Press.

Keisman, D. 2004. Ultimate recovery rates on bank loan and bond defaults. S \& P Loss Stats.

Matz, L. M. \& Neu, P. 1998. Liquidity risk measurement and management. New York: John Wiley and Sons Publishers.

Nworji, I. D., Olagunju, A. \& Adeyanju, D. O. 2011. Corporate governance and bank failure in Nigeria: Issues, challenges and opportunities. Research Journal of Finance and Accounting, Vol 2, No 2.

Ojo, J. A. T. 1999. Roles and failures of financial intermediation by banks. CBN Bullion, 23(3: 10-12.

Olokoyo, F. 0. 2011. Determinants of commercial banks' lending behavior in Nigeria. International Journal of Financial Research; Vol. 2, No. 2; July.

Oloyede, B. 1999. Principles of money and banking. Ado Ekiti, Nigeria: Forthright Educational Publishers.

Osayameh, R. 1991. Lending and credit administration model for commercial banks. Nigerian Financial Review, 4(2):55-60.

Osayameh, R. 1996. Practice of banking: Lending and finance, Vol. 2, Lagos: F.A. Publishers.

Pagano, M. 2004. Using an alternative estimation method to perform comprehensive empirical test: An application to interest rate risk management. Review of Quantitative Finance and Accounting, 23: 377- 406. http://dx.doi.org/10.1023/B:REQU.0000049322.82965.cc

Petersen, M. A. \& Rajan, R. G. 1995. The effect of credit market competition on lending relationships. The Quarterly Journal of Economics; 110 (2): 407-443. http://dx.doi.org/10.2307/2118445

Ramos, S. J. 2000. Financial Risk Management: Inter-American Development Bank.

Santomero, A. 1997. Commercial bank risk management: An analysis of the process. Journal of Financial Services Research, 12(2-3): 83-115. http://dx.doi.org/10.1023/A:1007971801810

Seppala, J. 2000. The term structure of real interest rates: Theory and evidence from U.K. Index-Linked Bonds. Department of Economics, University of Illinois at Urbana; Champaign, September.

Usman, S. 1999. Bank regulation and supervision in Nigeria. The Nigerian Banker, pp 7-9.

Varma, P., Cantor, R. \& Hamilton, D. 2003. Recovery rates on defaulted corporate bonds and preferred stocks. Moody's Investors Service, December.

Wenner, M., Navajas, S., Trivelli, C. \& Tarazona, A. 2007. Managing credit risk in rural financial institutions in Latin America. Inter-American Development Bank, Sustainable Development Department, Best Practices Series: Washington, D.C. Retrieved from http://idbdocs.iadb.org/wsdocs/getdocument. aspx?docnum=1442364 